\begin{tabular}{|c|c|c|}
\hline $\begin{array}{l}\text { 3. Poor nutritional } \\
\text { intake }\end{array}$ & $\begin{array}{l}\text { People who drink alcohol dependently commonly report } \\
\text { poor diet/oral intake and may present to hospital in } \\
\text { refeeding syndrome and very malnourished. Diarrhoea } \\
\text { and vomiting are common and people who drink at } \\
\text { higher/dependent levels may also have gut } \\
\text { malabsorption. Specifically, high alcohol use is strongly } \\
\text { associated with thiamine (vitamin B1) deficiency. } \\
\text { Deranged electrolytes (due to refeeding syndrome and } \\
\text { high alcohol use) and thiamine deficiency are therefore } \\
\text { common in patients withdrawing from alcohol and may } \\
\text { contribute to confusion/agitation whilst also placing } \\
\text { patients at risk of other complications such as cardiac } \\
\text { arnthmias. }\end{array}$ & $\begin{array}{l}\text { - Dietician referral if concerns (as per usual trust policy) or if any indication of } \\
\text { refeeding syndrome (the medical team will be reviewing the need for this) } \\
\text { - Frequently prompt patient to eat - food chart if concerns } \\
\text { - Encourage oral fluids frequently } \\
\text { - Timely administration of IV/oral electrolyte replacement and IV Pabrinex/oral } \\
\text { vitamins as prescribed } \\
\text { - Patent cannula - ensure VIP score completed/cannula care as per trust policy } \\
\text { BGL monitoring (as per section 1) }\end{array}$ \\
\hline $\begin{array}{l}\text { 4. Maintaining a } \\
\text { safe environment }\end{array}$ & $\begin{array}{l}\text { Patients in withdrawal may become agitated, aggressive } \\
\text { or hallucinate. Patients will not be aware they are doing } \\
\text { this - this is not a patient 'behaving badly', they are } \\
\text { critically unwell. Patients may try to leave the ward. They } \\
\text { may not be safe to be left unsupervised. They may be } \\
\text { unsteady on their feet and at risk of falls. }\end{array}$ & $\begin{array}{l}\text { - Nurse in a calm, well-lit and well-ventilated environment - minimise noise and } \\
\text { activity where possible (also see section 5) } \\
\text { - Ensure nicotine replacement is offered/prescribed if applicable (patient may be } \\
\text { trying to leave to have a cigarette, nicotine replacement may reduce irritability) } \\
\text { - Can they be moved to a quieter side room or a bed visible from the nurse's station } \\
\text { (whichever is most appropriate)? } \\
\text { - Do they need to be under a DOLS? Are you concerned about their capacity to refuse } \\
\text { treatment or leave? Raise with medical team if so } \\
\text { - Request } 1: 1 \text { staffing, } 2: 1 \text { staffing may even be required at times, staff safety is } \\
\text { paramount. Discuss with bleep holder/matron. Please see the Enhanced Care } \\
\text { Observation Policy (Sept 2020) on StaffNet (formerly called the specialling policy) for } \\
\text { further guidance if close observation is indicated. } \\
\text { - Falls prevention care (as per trust policy) - ensure they have appropriate footwear on, } \\
\text { keep bedspace clear of trip hazards, ensure walking aids are to hand if used etc. }\end{array}$ \\
\hline $\begin{array}{l}\text { 5. Impaired } \\
\text { communication }\end{array}$ & $\begin{array}{l}\text { Patients are often anxious, agitated and/or may be } \\
\text { hallucinating. They may not be able to express their } \\
\text { concerns and may not understand what is happening } \\
\text { around them. Withdrawal from alcohol can be really } \\
\text { frightening. Reassurance and good communication skills } \\
\text { are vital. } \\
\text { Of note, people in alcohol withdrawal/DTs may speak } \\
\text { their first language if English is a second language (even } \\
\text { if they usually speak English well). }\end{array}$ & $\begin{array}{l}\text { - If English not spoken/understood - can we use language line? Can they be cared for } \\
\text { by a member of staff who speaks their language? } \\
\text { - Ensure baseline communication aids are working and being used (e.g., hearing aids) } \\
\text { - Try to create a calm environment by using lower tone/volume of voice, avoid } \\
\text { confrontation/grabbing/restraining (unless there is an immediate risk of serious } \\
\text { injury/harm to patient or others in which case reasonable and proportionate force } \\
\text { can be used), make instructions clear and minimal, keep the environment quiet as far } \\
\text { as you can } \\
\text { - Reassure patient regularly, do not challenge delusions but gently reorientate them to } \\
\text { where they are and what is happening } \\
\text { - Ensure family are involved in care - via phone or visits (as permitted) }\end{array}$ \\
\hline $\begin{array}{l}\text { 6. Assistance with } \\
\text { personal care }\end{array}$ & $\begin{array}{l}\text { People in alcohol withdrawal may be unable to meet } \\
\text { their own self-care needs/activities of daily living } \\
\text { temporarily. }\end{array}$ & $\begin{array}{l}\text { - Assist with washing and dressing as required } \\
\text { - Prompt to use the toilet regularly - provide care if incontinent } \\
\text { - Frequent bed/clothes changes - profuse sweating is common in alcohol withdrawal } \\
\text { - Consider pressure area care }\end{array}$ \\
\hline $\begin{array}{l}\text { 7. Emergency } \\
\text { preparedness }\end{array}$ & $\begin{array}{l}\text { Delirium tremens, seizures and cardiac arrest are } \\
\text { complications of withdrawal that we aim to avoid by } \\
\text { providing the care in the plan above. } \\
\text { However, in rare situations these may occur. It is } \\
\text { important to be prepared for this and to know what to } \\
\text { do should they arise. }\end{array}$ & $\begin{array}{l}\text { - Check bedside safety equipment at the start of each shift- do you have working } \\
\text { suction at the bedside? Is there a non-rebreathe mask available and a nipple on the } \\
\text { bedside oxygen? } \\
\text { - Do you know where the crash trolley is? } \\
\text { - Do you know the emergency numbers for the crash team in case of seizure/cardiac } \\
\text { arrest (2222) and security if the patient is aggressive or tries to leave (and is under } \\
\text { DOLS)? (3333) } \\
\text { - Notify the medical team and Alcohol Care Team if you are struggling to manage the } \\
\text { patient's withdrawal (remember to evaluate the care you are giving throughout the } \\
\text { shift - is it working? Get help if it isn't) } \\
\text { - Be familiar with the Management of Delirium Tremens protocol**. Think ahead - if } \\
\text { you are worried your patient is moving in this direction have this to hand, ensure the } \\
\text { necessary drugs have been prescribed and medical and alcohol teams are aware. } \\
\text { - The alcohol nurses are happy to come and help stabilise patients in withdrawal } \\
\text { (bleep 1808. Ext 5721) }\end{array}$ \\
\hline
\end{tabular}

Abstract P020 Figure 1 Nursing care plan: acute alcohol withdrawal (attached)

\section{P021 REVIEW OF IMPACT OF COVID 19 ON HEPATOCELLULAR CARCINOMAS (HCCS) PRESENTED AT THE NORTHERN IRELAND (NI) REGIONAL MDM}

Rebecca O' Kane*, Neil McDougall. Royal Victoria Hospital, UK

\subsection{6/gutjnl-2021-BASL.30}

Introduction The COVID 19 pandemic has impacted the management of most patients including those with chronic liver disease. HCC usually arises in patients with liver cirrhosis and the Belfast Trust HCC screening program was suspended for 3 months in 2020.
Our aim was to assess the number and source of referrals along with treatment outcomes for 2020 compared to 2019. Methods The regional HPB MDM database was reviewed to identify all HCC cases during a 12 month period from 1st January 2020. Results were compared with an audit of HPB MDM outcomes from 2019.

Results 80 patients with HCC were identified, compared to 82 in 2019. There was a reduction in referrals as expected in the second quarter of 2020 , as illustrated in the table 1 .

$12(15 \%)$ patients were detected via HCC screening programme, compared to $19(23 \%)$ in 2019. 


\begin{tabular}{lll} 
Abstract P021 Table & \multicolumn{2}{l}{ Results: referral numbers } \\
\hline & 2019 & 2020 \\
\hline Jan-March & 17 & 16 \\
April-June & 22 & 11 \\
July-Sept & 17 & 25 \\
Oct-Dec & 26 & 28 \\
\hline
\end{tabular}

36 patients $(45 \%)$ were offered surgical (6) or radiological (30) therapy in 2020 compared to 32 in 2019.

Similar radiological therapy was recommended both years. The main difference in surgical treatment was that only 3 resections were undertaken in 2020, compared to 7 in 2019. In 2020, 2 patients were referred for transplant assessment in November and December 2020 (none referred earlier in year), with 3 referred in 2019.

Palliative care was recommended for 44 (55\%) patients in 2020 , which was similar to $48(58 \%)$ of patients in 2019 . In 2020, 10 patients were referred for systemic therapy (17 in 2019). 2 patients received sorafenib compared to 7 the previous year.

Of those referred for palliative care, 17 had treatable disease but the patient was not fit for treatment while another 17 had extensive/metastatic disease and so were recommended for supportive care.

Conclusion COVID 19 may have had an impact on referral patterns and HCC screening programs in 2020. However, the total number of HCC cases referred to the regional HPB MDM in 2020 was as expected and the treatment options recommended were very similar to 2019. The only substantial difference was a reduction in the number of patients who were commenced on systemic therapy.

\section{P022 CLINICAL PRESENTATION AND OUTCOMES OF WILSON'S DISEASE: A SINGLE CENTRE COHORT STUDY}

Akhilesh Mulay*, James Dooley, Emmanouil Tsochatzis. UCL Institute for Liver and Digestive Health, Royal Free Hospital and UCL, London, UK

\subsection{6/gutjnl-2021-BASL.31}

Introduction Wilson's Disease is a disorder of copper homeostasis leading to hepatic and neuropsychiatric disease. Clinical data on these patients are limited due to low disease frequency. This report explores the presentation, management and outcomes of a large cohort of patients with Wilson's disease including pregnancy outcomes.

Methods A retrospective analysis was performed on 63 patients with Wilson's disease managed at the Royal Free Hospital, London, between 2012 and 2021. Clinical data were collected on presenting features, investigations, treatments and outcomes.

Results The mean age at diagnosis was 20 years (range 7-54 years) with 38 patients presenting due to liver involvement, 13 due to neuropsychiatric disease, 4 with both and 8 due to family screening. Of those presenting with liver involvement, $43 \%$ had asymptomatic liver disease with incidentally identified abnormal liver blood tests. The mean delay between onset of symptoms and diagnosis was 2 years (max. 8 years). During disease management, 31 patients received one type of drug treatment while 32 received more than one. In total, 48 patients received Penicillamine; of these, 11 were noncompliant to treatment, 16 experienced adverse effects and 21 stopped treatment. The most common adverse effect was skin changes (38\% of patients). In patients who stopped Penicillamine, $67 \%$ did so due to adverse effects. Trientine was given to 25 patients ( 1 noncompliant, 2 with adverse effects and 6 stopped treatment) while Zinc was given to 22 patients (4 noncompliant, 3 with adverse effects and 8 stopped treatment). At latest follow-up (mean 10.2 years), 92\% of patients with symptomatic liver disease, $87 \%$ with neurological disease and $89 \%$ with psychiatric symptoms had clinically improved or were stable. In patients with no psychiatric involvement at diagnosis, 26\% developed new psychiatric symptoms. Four patients underwent liver transplant, 3 due to decompensated cirrhosis and 1 due to acute liver failure. There were 3 deaths, of which 2 were due to liver-related complications. Seven patients had 12 pregnancies; 10 were on Penicillamine and 2 were on Zinc therapy throughout the pregnancy. Of those pregnancies on Penicillamine, 8 were normal, 1 was a miscarriage and 1 was a termination. Both pregnancies on Zinc were normal.

Conclusions The majority of patients with Wilson's disease who present primarily with liver involvement are asymptomatic with incidentally identified abnormal liver blood tests. New psychiatric symptoms commonly develop after diagnosis and may warrant more proactive psychological input. Penicillamine and Zinc appear to be safe in pregnancy.

\section{P023 THE EFFECTIVE USE OF BEZAFIBRATE AS A SECOND LINE THERAPY FOR PRIMARY BILIARY CHOLANGITIS}

Adam Howden*, Talal Valliani. North Bristol NHS Trust Liver Unit, UK

\subsection{6/gutjnl-2021-BASL.32}

Background Bezafibrate, a peroxisome proliferator-activated receptor alpha agonist, is not often used in the UK for treatment of PBC (primary biliary cholangitis) in patients who don't respond to ursodeoxycholic acid (UDCA) because it is an unlicensed therapy for this condition. In our liver unit we have used this treatment since 2014 .

Methods This retrospective case series included all patients who were commenced on bezafibrate from January 2014 to March 2020. 25 patients were listed from our pharmacy database and notes reviewed using a data collection tool. Biochemical and clinical outcomes were recorded over a 12 month period following initiation of bezafibrate in combination with UDCA.

10 patients were excluded due to either: non-compliance; a revised diagnosis of an overlap syndrome or primary sclerosing cholangitis; less than 12 months duration of bezafibrate therapy; lost to follow-up; not fulfilling PBC diagnostic criteria as per The British Society Gastroenterology/UK-PBC management guidelines. ${ }^{1}$

An inadequate response to UDCA therapy was defined by the 'Toronto' biochemical stratification as a serum alkaline phosphatase (ALP) level above $1.67 \mathrm{x}$ upper limit of normal (normal range $30-130 \mathrm{U} / \mathrm{L}$ ). This value is $217 \mathrm{U} / \mathrm{L}$ in our unit.

Results The 15 patients were all female with a median age at diagnosis of $49.67 \%$ were positive for anti-mitochondrial antibody or PBC specific anti-nuclear antibody. 33\% had consistent liver histology and the median ALP was $477 \mathrm{U} / \mathrm{L}$ at 